\title{
Specificity of Grain Maize Cultivation with Irrigation under Conditions of Forest Steppe of the Republic of Ingushetia
}

\author{
M A Bazgiev1', K Sh Badurgova², M U Gambotova ${ }^{3}$, B B Galaev', and \\ F A Biteyeva ${ }^{3}$
}

${ }^{1}$ Research and Development Institute of Agriculture, Sunzha, Republic of Ingushetia, Russia ${ }^{2}$ Deputy director for R\&D, Sunzha, Republic of Ingushetia, Russia

${ }^{3}$ Section of Agroecology and dry-land cultivation, Research and Development Institute of Agriculture, Sunzha, Republic of Ingushetia, Russia

${ }^{4}$ Section of Horticultivation and potato cultivation, Research and Development Institute of Agriculture, Sunzha, Republic of Ingushetia, Russia

\section{Abstract}

An important condition of rational usage of irrigation water is the determination and regulation of water consumption by grain maize at main growth phases providing maximum product yield per unit water supplied. The establishment of

Corresponding Author:

M A Bazgiev

ishos06@mail.ru

Received: 25 October 2019 Accepted: 15 November 2019 Published: 25 November 2019

Publishing services provided by Knowledge E

(c) M A Bazgiev et al. This article is distributed under the terms of the Creative Commons

Attribution License, which permits unrestricted use and redistribution provided that the original author and source are credited.

Selection and Peer-review under the responsibility of the AgroSMART 2019 Conference Committee.

\section{G OPEN ACCESS} water consumption for growth periods will allow planning the irrigation regime and determining rates of water consumption and discharge. The research has shown that bioclimatic coefficients in all cases increase beginning with sprouting stage and maximize at the phase of paniculation, milky-wax ripeness, and then decreases again. The obtained data were used to calculate the bioclimatic coefficients of water consumption by grain maize using the interphase vegetation periods, from sprouts to ripening. Thus, the implemented calculation methods of total evaporation are local, and increased calculation accuracy requires determining them experimentally in specific climatic conditions.

Keywords: amelioration, irrigation rates, differential irrigation regime, critical phases, total water consumption

\section{Introduction}

The main limiting factor in steppe region farming is insufficient and nonstable water supply of agricultural crops during the vital phases of development. This factor appreciably determines the amount, quality and stability of harvest and necessity of irrigation ameliorations [1, 2, 4].

However, over the recent years, the area of irrigated land in Russia has considerably reduced (by 20--30\%), while the efficacy of their usage has dropped by more than $50 \%$. The yield of irrigated lands decreased 1.5--3 times, the technical condition of irrigation system, provision by irrigation equipment, tools for controlling irrigation and 
water counting have deteriorated; the irrigation land cultivation culture has unacceptably decreased in general $[4,7]$.

The Republic of Ingushetia is no exception. Fertile lands in combination with optimal heat climatic resources provide favorable conditions for high yield of grain crops, vegetables and industrial crops. The only inhibitor is naturally insufficient watering of the area $[4,8]$. In such conditions, only irrigation can rejuvenate the deficit of water balance and increase the productivity of the land. Irrigation allows introducing to the cultivated land of moisture-loving crops that increase the yield and facilitate harvest quality. One of such crops, responsible to irrigation and capable of solving the problem of concentrated food production, is grain maize. Thus, we were to study the biological peculiarities of growth and development of maize under irrigation. The development of its cultivation technologies will unveil the main directions to increased productivity of these crops and augmented efficiency of the irrigated land.

\section{Research Goal}

To investigate the specificities of grain maize cultivation under conditions of irrigation for the farms of the AIC in the Republic of Ingushetia.

\section{Research Tasks}

1. To develop a technology for grain maize cultivation on irrigated lands of forest steppes in the Republic of Ingushetia.

2. To develop optimal regimes of maize irrigation, to determine daily expenditure and total water consumption depending on the demanded soil moisture.

3. To study the peculiarities of growth and development of maize plants at different water supply levels.

4. To identify the productivity of maize depending on the cultivation regimes and irrigation regimes.

\section{Experimental Scheme}

To study the regimes of irrigation and water consumption by grain maize under conditions of the Republic of Ingushetia.

Variant 1. Irrigation after soil moisture drops to $80 \%$ of SM. 
Variant 2. Irrigation after soil moisture drops to $70 \%$ of SM (reference).

Variant 3. Irrigation after soil moisture drops to $60 \%$ of SM.

Variant 4. Maintenance of soil moisture at a level from 70 to $90 \%$ of SM.

Variant 5. Maintenance of soil moisture at a level from 60 to $80 \%$ of SM.

Variant 6. No irrigation.

For all variants, the calculated soil wetting layer amounted to $0.6 \mathrm{~m}$. During development and justification of the irrigation regime and water consumption by grain maize for variants 4 and 5 , the soil moisture was maintained between $70--90 \%$ of SM and $60--80 \%$ of SM, i.e. in calculation of irrigation rates, the soil moisture was below $100 \%$ of SM, while for variant 4 , from 70 to $90 \%$ of SM, and for variant 5 , from 60 to $80 \%$ of $\mathrm{SM}$. The irrigation rates for variants 1,4 and 5 were equal to $400 \mathrm{~m}^{3} / \mathrm{ha}$, because the calculated soil moisture in all cases was increasing by $20 \%$ of SM, i.e. from 80 to 100 $\%$ of SM for variant 1 , from 70 to $90 \%$ of SM for variant 4 and from 60 to $80 \%$ of SM for variant 5 . The irrigation conditions were different for these variants.

The calculated irrigation rates for soil layer wetting of $0.6 \mathrm{~m}$ amount to: $402 \mathrm{~m}^{3} / \mathrm{ha}$ for variant 1 at lower threshold $80 \%$ of SM; $602 \mathrm{~m}^{3} /$ ha for variant 2 (reference) at $70 \%$ of SM; and $800 \mathrm{~m}^{3} /$ ha for variant 3 at $60 \%$ of SM.

The irrigation for all variants was carried out by DDA-100MA sprinkling machine. The experimental plots were 30 meters wide; the length was a factor of the irrigation machine span and equaled to 110 meters. The long side of the plots was traverse to the temporary irrigator. The total area of the plot was $3300 \mathrm{~m}^{2}$, the accounting area was $200 \mathrm{~m}^{2}$. The experiment had three replications.

\section{Materials and Methods}

The irrigation regime, methods of irrigation and fertilization of grain maize were studied by the techniques presented in the works of B.A. Dospekhov, methodological guidelines developed at R\&D Institute of Feed named after V.R. Wiliams and other generally accepted methods for establishing and performing field experiments.

To obtain adequate results and objectively evaluate them, for all the variants the following observations and studies were carried out:

1. Phenological observations were made for all experiments. The following growth phases were noted: sprouting, 5th leaf, paniculation, panicle flowering, occurrence of corn silk, ripening (milky, wax, full). 
2. The density of plants was determined at each plot in two places diagonally at 10 $\mathrm{m}^{2}$ at different phases: full sprouting and harvesting.

3. The linear growth was accounted on dynamic platforms at 25 selected plants in two locations of the plot.

4. The dynamics of green mass development, dry matter accumulation and yield analysis were performed by the method of R\&D Institute of Feed.

5. The development of maize root system was observed by triple replication. The root mass was determined in one-meter layer by the method of N.Z. Stankov [13]. The monolith sample area was $0.125 \mathrm{~m}^{3}(70 \times 18 \mathrm{~cm})$. The evolution of the root system along the horizons was determined by dry digging.

6. The soil nutrient status was determined by sampling before fertilizing to determine the fertilizer dosage, during sowing, as per growth phases, and during harvesting in two soil layers: ploughed layer $(0--30 \mathrm{~cm})$, and subsurface soil $(30--50 \mathrm{~cm})$. The soil samples were used to determine the dry residue and its composition, nitrate nitrogen, easily hydrolyzed nitrogen, labile phosphorus by the method of Myachigin, exchange potassium by the method of Maslova.

7. Water-physical properties of soil (density, specific mass, porosity and lowest water capacity) were determined by the techniques presented in ameliorative soil science by V.S. Astapov.

8. The soil moisture was determined by the thermostatic weight method; the samples were taken each 7--10 days, as well as before and after irrigation and precipitation more than $5 \mathrm{~mm}$ every $10 \mathrm{~cm}$ up to the depth of one meter.

9. The irrigation rate was calculated by the equation of A.N. Kostyakov,

$$
\mathrm{m}=100 * \mathrm{H} * \mathrm{a} *\left(\mathrm{~B}_{S M}-\mathrm{B}_{H}\right)
$$

10. The water consumption of grain maize was determined by the method of water balance with due consideration of moist reserve in soil in the beginning and at the end of vegetation, irrigation rate and precipitation over the vegetation period by the following equation:

$$
T+\ni=W_{0}+P+M-W
$$

Besides, the total water consumption of maize was determined by the bioclimatic method.

11. The irrigation water during sprinkling was accounted by water meter WD-180 mounted on the DDA-100 MA machine. 
12. The grain maize yield was accounted on the plot by Don-1500 combine with an extension for grain threshing with grain sampling of $2 \mathrm{~kg}$ to analyze its physical qualities and dockage. The grain moisture was reduced to $14 \%$.

13. The mathematical processing of maize grain yield was done by the dispersion method.

14. Economical efficacy of the agro-methods was determined by flow process charts, composition of expenses for production, harvesting and transportation of the product, and its sales value.

\section{Results and Discussion}

The optimization of irrigation regimes was aimed at the elaboration of such irrigation rate, moisture threshold and soil wetting depth, which would provide maximum specific yield at minimum water expenditure per unit product.

These problems were covered in a number of studies that determined an optimal regime of grain maize irrigation and investigated --- for different soil and climate zones --- the admissible preirrigation thresholds, soil wetting depth and various irrigation rates aimed at increased yield. However, the opinions of the researchers are very diverse.

Many authors have established [1, 2, 11] that the lower threshold of optimal soil moisture for grain maize lies within $65--85 \%$ of SM and depends on specific soil and climate conditions of crop cultivation and its biological specificities.

Due to uneven water demand of different plants during the vegetation period, a number of researchers recommend implementing the differentiated regime of maize irrigation as per its development phases: the reduction of moisture down to $65--70 \%$ of $\mathrm{SM}$ at the initial development period and maintaining it at least at $75--80 \%$ of SM during its critical development phases (paniculation and milky ripening [2--4] and reduction of soil moisture down to $65--70 \%$ of SM at the end of the vegetation period $[1,8]$.

It was also established that maize is most sensitive to water shortage during paniculation and water ripening. The daily water expenditure during this period was 50--70 $\mathrm{m}^{3} / \mathrm{ha}[5,6]$. The shortage of water at the critical maize development period caused grain yield reduction by $50 \%$, while the only watering during the critical phase (paniculation) increased the maize grain yield from 32 to $82 \mathrm{dt} / \mathrm{ha}[9,10,14]$.

The analysis of the study results showed that in maize growing, the soil moisture in the layer where the main amount of roots is situated should not drop below 75--80 \% of SM. The critical factor for high yield is creation of optimal water regime during the 
whole vegetation period, especially during critical water consumption period beginning 1--12 days before paniculation and lasting up to milky grain ripeness [10--12].

The irrigation rates and the number of maize watering operations depend on the soil density, wetted layer and irrigation threshold, mechanical soil composition, ground water depth, soil and air temperature, air speed, density of plants and other factors.

Thus, we established that during maize irrigation, depending on soil, climatic and other conditions, such parameters as the lower threshold of soil moisture, wetting depth, irrigation and sprinkling rate vary quite appreciably. That is why their values with due account for the biological peculiarities and development phases of maize can be established only by field studies in specific soil and climatic conditions.

On the irrigated lands the cultivation of grain maize has a number of specificities connected with morphobiological structure of maize plants and different demand for heat, feed, lighting and other factors for productivity formation.

In this connection, a particular importance has the selection of highly productive maize breeds and hybrids responsive to irrigation and investigation of their reaction for irrigation conditions during different phenological phases. It is important to learn the dynamics of linear growth, leaf surface, dry matter accumulation.

A major effect on formation and development of generative organs (flowers and seeds) is made by water availability of soil and air humidity. This is why that determination of necessary watering conditions and methods of regulation of generative organ formation are the basics for plant productivity enhancement.

An important condition of rational usage of irrigation water is the determination and regulation of water consumption by grain maize at main growth phases providing maximum product yield per unit water supplied. The establishment of water consumption for growth periods will allow planning the irrigation regime and determining norms of water consumption and discharge.

Our studies demonstrated that the largest specific fraction in total water consumption is $57--58 \%$ from precipitation, $18--37 \%$ from irrigation water and $6--22 \%$ from soil water.

Despite the highest indicator of total water consumption for variant $1\left(5470 \mathrm{~m}^{3} / \mathrm{ha}\right)$, the water availability conditions were better as compared to other variants. It demonstrated the highest grain yield of $10.51 \mathrm{t} / \mathrm{ha}$ and the lowest water expenditure. The coefficient of water consumption of total water consumption amounted to $539 \mathrm{~m}^{3} / \mathrm{t}$ (Table 1).

The deterioration of water availability reduces the total water consumption; however, the yield also drops, so the efficacy of water usage decreases. Indeed, the water expenditure for 1 ton of grain maize for variant 2 increases up to $580 \mathrm{~m}^{3} / \mathrm{t}$, while for 
TABLE 1: Efficacy of irrigation water usage (averaged over 3 years).

\begin{tabular}{l|l|c|c|c|c|}
\hline Variants & $\begin{array}{c}\text { Total water } \\
\text { consump- } \\
\text { tion } \\
{\left[\mathrm{m}^{3} / \mathrm{ha}\right]}\end{array}$ & $\begin{array}{c}\text { Grain yield } \\
{[\mathrm{t} / \mathrm{ha}]}\end{array}$ & $\begin{array}{c}\text { Coefficient } \\
\text { of water } \\
\text { consump- } \\
\text { tion } \\
{\left[\mathrm{m}^{3} / \mathrm{t}\right]}\end{array}$ & Coefficient of irrigation water usage * \\
\hline
\end{tabular}

Note: * Relation of irrigation rate to yield surplus

variant 3 that is $746 \mathrm{~m}^{3} / \mathrm{t}$. For variant 4 , where the soil moisture was maintained at $70--90$ $\%$ of SM, the coefficient of water consumption increased up to $651 \mathrm{~m}^{3} / \mathrm{t}$. However, as compared to variant 1 , the irrigation rate decreased by $530 \mathrm{~m}^{3} /$ ha from 2000 to 1470 $\mathrm{m}^{3} / \mathrm{ha}$, so for this variant the coefficient of irrigation water usage amounted to $299 \mathrm{~m}^{3}$ per ton of yield surplus.

The efficacy of irrigation water usage on other irrigated variants declines, because the formation of 1 ton of yield surplus required: $317 \mathrm{~m}^{3} / \mathrm{t}$ for reference variant, $349 \mathrm{~m}^{3} / \mathrm{t}$ for variant 2 , while for variant 3 it increased up to $568 \mathrm{~m}^{3} / \mathrm{t}$.

During the vegetation period in different growth and development phases, the total water consumption by maize changes and depends on water availability increasing from sprouting to paniculation and decreasing from milky-wax to full ripening of the grain.

The investigation has established that total water consumption and average daily water consumption by maize tends to increase with improvement of water availability. While for the variant with no irrigation, the total water expenditure over grain maize vegetation period amounted to $3890 \mathrm{~m}^{3} /$ ha, the irrigation of variant 1 consumes 5470 $\mathrm{m}^{3} / \mathrm{ha}$. The average daily water consumption changes from 37 to $43 \mathrm{~m}^{3} / \mathrm{ha}$. 
Thus, under conditions of the Republic of Ingushetia, for optimal irrigation regime of grain maize ( $80 \%$ of SM in 0.6 layer for variant 1 ), the total water consumption amounts to $5470 \mathrm{~m}^{3} /$ ha, while the water consumption coefficient equals $539 \mathrm{~m}^{3} / \mathrm{t}$.

The largest average daily water consumption for variants 1--4 is observed during the period from 10 leaves to paniculation (57-- $60 \mathrm{~m}^{3} / \mathrm{ha}$ a day); in the beginning and at the end of vegetation, the water consumption decreases 2 times and more.

Currently, the total evaporation is mainly determined by three methods: method of water balance, methods based on determination of water steam streams in atmosphere, including the method of energy consumption measurement for evaporation, so called method of heat balance and calculation methods of evaporation determination.

We determined the evaporation (water consumption) by four methods: method of water balance, method of S.M. Alpatyev, method of G.K. Lgov and method of D.A. Shtoyko [1, 11]. The reference method was method of water balance (Table 2).

TABLE 2: Total evaporation of maize established by experiment and calculations, variant $1, \mathrm{~m}^{3} /$ ha (average over 3 years).

\begin{tabular}{|c|c|c|c|c|c|c|c|}
\hline \multirow[t]{2}{*}{ Calculation method } & \multicolumn{4}{|c|}{ Interphase vegetation periods } & \multirow{2}{*}{$\begin{array}{l}\text { Over } \\
\text { veget. } \\
\text { period }\end{array}$} & \multicolumn{2}{|c|}{ Deviation from $(\mathrm{K})$} \\
\hline & $\begin{array}{l}\text { Sprouts -- } \\
10 \text { leaves }\end{array}$ & $\begin{array}{l}10 \text { leaves } \\
-- \\
\text { paniculat- } \\
\text { ion }\end{array}$ & $\begin{array}{l}\text { Paniculation } \\
\text {-- milky-wax } \\
\text { ripening }\end{array}$ & $\begin{array}{l}\text { Milky-wax -- } \\
\text { full ripening }\end{array}$ & & $\mathrm{m}^{3} / \mathrm{ha}$ & [\%] \\
\hline Water balance (ref.) & 784 & 1641 & 1963 & 612 & 5000 & --25 & 0.4 \\
\hline Alpatyev & 858 & 1837 & 1947 & 636 & 5278 & --192 & 4 \\
\hline Lgov & 851 & 1816 & 1732 & 420 & 4819 & --651 & 12 \\
\hline Shtoyko & 678 & 1422 & 1824 & 474 & 4398 & --1072 & 19 \\
\hline
\end{tabular}

The method of water balance is based on the control of water availability in soil, as well as incoming and outgoing part of the water balance.

The method of Alpatyev is based on the usage of biological evaporation coefficients and sum of average daily air moisture deficit values.

Table 2 shows that the average discrepancy in total evaporation indicators determined by the water balance method and calculated by the methods of Alpatyev and Lgov amounts to --192 and $--651 \mathrm{~m}^{3} /$ ha, i.e. 4 and $12 \%$. This difference in the indicators of $0.5-1 \%$ was noted from the phase of 10 leaves and it also increased from milkywax ripening to full one up to 19 and $48 \%$, respectively. The largest difference of the calculated indicators of $19 \%$ was noted decreasingly from the water balance method when using the method of Shtoyko. 
According to Table 2, the method of Alpatyev can be recommended for industrial use as the most accurate.

Taking into account, that none of the methods provided $100 \%$ convergence with calculated figures, and the most justified methods are those based on implementation of biological evaporation curves, we assumed necessary to refine the bioclimatic coefficients for conditions of Ingushetia in connection with the sum of temperatures and soil moisture deficits.

The calculations used indicators of total evaporation by growth phases in soil layer of 1.0 meter for variant 1 and for resource-saving variant 4 . With known sum of temperatures and air moisture deficit, we determined these coefficients by the growth phases.

The dependence of the bioclimatic coefficients on total water consumption were processed on a computer. As a results, regression equations were derived for variants 1 and 4 with reliable approximation coefficients.

The research has shown that bioclimatic coefficients in all cases raise beginning with sprouts and maximize at the phase of paniculation, milky-wax ripeness, and then decreases again. The obtained data were used to calculate the bioclimatic coefficients of water consumption by grain maize using the interphase vegetation periods, from sprouts to ripening.

Thus, the implemented calculation methods of total evaporation are local, and increased calculation accuracy requires determining them experimentally in specific climatic conditions.

The considered methods at the initial and final development stages overestimate total maize evaporation, while at the stage of active vegetation, they underestimate it. In this connection, we have calculated the correction factors that allow correcting the total maize evaporation over the vegetation period.

The comparison of evaporation data obtained by the calculation method and measured by the method of water balance have demonstrated the best convergence of two methods: method of Alpatyev and method of Lgov.

The experimental data were used to refine the bioclimatic coefficient for calculating evaporation by the methods of S.M. Alpatyev calculated by the sum of temperatures and by the method of Lgov calculated by the sum of air moisture deficit values.

We have calculated the biological coefficients by interphase periods of maize vegetation and established that in the phases of active vegetation, the total maize evaporation even at optimal irrigation exceeds the evaporation from the water surface. 


\section{Conclusions}

1. The main components of total water consumption are precipitation and irrigation rate.

2. The largest average daily water consumption for variants $1-4$ is observed during the period from 10 leaves to paniculation (57--60 $\mathrm{m}^{3} /$ ha a day); in the beginning and at the end of vegetation, the water consumption decreases 2 times and more.

3. Statistically justified bioclomatic coefficients were obtained for grain maize which allow more accurately calculating and correcting the irrigation regime.

4. The most accurate calculation method for total evaporation determination and selection of the irrigation regime are methods of S.M. Alpatyev, implementing the obtained bioclimatic coefficients using the sum of average daily sir moisture deficit values, and that of Lgov, implementing the sum of cumulative average daily air temperatures beginning from the sprouting stage.

\section{Conclusions}

Under the conditions of irrigation in the forest steppe zone of the Republic of Ingushetia on maize areas, it is recommended to maintain the soil moisture in 0.6-meter layer close to $80 \%$ of SM with the irrigation rate of $2000 \mathrm{m3} / \mathrm{ha}$, which correspondingly provides the yield surplus of up to $4.3 \mathrm{t} / \mathrm{ha}$.

\section{References}

[1] Alpatyev, S.M. (1965). Irrigation regime of agricultural crops in the southern part of Ukraine. Kiev: Press of Ukranian Ministry of Agriculture, 88 p.

[2] Akhtyrtsev, M.G. (2002). Productivity of seed corn depending on the methods of its cultivation on common chernozem of western Fore-Caucasus. PhD dissertation thesis. Krasnodar, 24 p.

[3] Bagrintseva, B.N. (2006)..Agrokhimiya, no. 6, pp. 33--44.

[4] Barkinhoev M.M. et al. (2002). Natural and climatic resources of Ingushetia. Nalchik: Elfa Press, pp. 137--141.

[5] Dospekhov, B.A. (1985). Methods of field experiment. Moscow: Agropromizdat.

[6] Zherukova, A. (2006). Market of maize grain of the Southern Federal District of Russia. A/C: economics, management, no. 6, pp. 32--33.

[7] Ilyin, B.C., Ilyin, I.V. (2001). Early-ripe corn: state and perspectives. Omsk, 172 p. 
[8] Kolganov, A.V., Viksne, A.A., Shchedrin, V.N. et al. (2000). Amelioration state of agricultural lands in the Russian Federation and solutions for crisis. Moscow, 150 p.

[9] Koldaeva, I.P. (2004). Corn in funny pop style. Pokupatel, no. 4, pp. 32--34.

[10] Kislinskiy, K.N. (2004)..Productivity of corn hybrids. Grain industry, no. 8, pp. 23.

[11] Lgov, G.K. (1973). Irrigation of grain maize. Hydromachines and amelioration, no. 4, pp. 50--53.

[12] Maier, A.V. (2006). Irrigation of grain maize in Lower Volga region. Chief agronome, no. 6 , pp. 77--78.

[13] Stankov, N.Z. (1964). Root system of field crops. Moscow: Kolos.

[14] Shishkin, V.O. (2001). Management and economic principles of amelioration development. Rostov-on-Don: Press of North-Caucasian Scientific Center of Higher School, $163 \mathrm{p}$. 